\title{
Cyanogenic Potential of Selected Cassava Varieties in Zombo District, Uganda
}

\author{
Benson Oloya ${ }^{1,{ }^{*}, \text { Christopher Adaku }}{ }^{2}$, Emmanuel Ntambi ${ }^{2}$, Morgan Andama ${ }^{3}$ \\ ${ }^{1}$ Department of Chemistry, Muni University, Arua, Uganda \\ ${ }^{2}$ Department of Chemistry, Mbarara University of Science and Technology, Mbarara, Uganda \\ ${ }^{3}$ Department of Biology, Mbarara University of Science and Technology, Mbarara, Uganda
}

Email address:

oloyabenson@gmail.com (B. Oloya),b.oloya@muni.ac.ug (B. Oloya)

${ }^{*}$ Corresponding author

\section{To cite this article:}

Benson Oloya, Christopher Adaku, Emmanuel Ntambi, Morgan Andama. Cyanogenic Potential of Selected Cassava Varieties in Zombo District, Uganda. International Journal of Nutrition and Food Sciences. Vol. 6, No. 3, 2017, pp. 144-148. doi: 10.11648/j.ijnfs.20170603.16

Received: March 21, 2017; Accepted: April 10, 2017; Published: May 25, 2017

\begin{abstract}
Both improved and local cassava varieties are widely grown and also, consumed in Zombo district as well as West Nile Sub region and Uganda as a whole. However, all cassava varieties contain cyanogenic glycosides which are toxic, although the amounts in each cultivar may vary considerably. Consumption of such toxins in sufficient quantities poses a health risk since they can cause acute cyanide poisoning and death in humans and animals. As such, information concerning the cyanogenic glycosides content in cassava cultivars is indispensable in averting health risks linked with cassava consumption. In this study, the cyanogenic content of the most common local cassava varieties (Bisimwenge, Nyar-anderiano, Nya-matia, Nya-pamitu, Nya-papoga and Nyar-udota) grown in Zombo district and six improved cassava varieties (NASE 3, NASE 9, NASE 14, NASE 19, TME 14 and TME 204) were investigated. Generally, the improved cassava varieties revealed lower levels (mean value was $108.75 \mathrm{mg} / \mathrm{kg}$ ) of cyanogens than the local varieties (mean value was $201.65 \mathrm{mg} / \mathrm{kg}$ ). The concentrations of the cyanogen in all the cultivars investigated were far above the FAO/WHO recommended value $(<10$ $\mathrm{mg} / \mathrm{kg}$ ). Hence, adequate detoxification and reduced frequency of consumption of these cassava cultivars are necessary in order to limit the ingestion of toxic levels of cyanide.
\end{abstract}

Keywords: Cassava, Cyanogenic Glycosides, Cyanide Poisoning, Food Security

\section{Introduction}

Cassava is the second most important staple food in Uganda with per capita consumption of $132 \mathrm{~kg}$, accounting for about $13 \%$ of the caloric intake [1]. In Zombo district, cassava is the most dominant crop with about $72 \%$ of households growing it [2].

Traditionally, cassava has served as a food security crop, grown as a form of insurance against drought and the failure of other staple crops. Mainly, planting is done in the first rather than the second rains of the year, and it is usually intercropped often with sweet potato, beans and maize [3]. Because of the apparent agricultural benefits of growing cassava and growing demand for food due to the population pressures, cassava usage is being extended to some regions in Africa and elsewhere in which it was not previously used [4].
Nevertheless, cassava has some poisonous compounds, the cyanogenic glycosides for example, linamarin (about 95\%) and lotaustralin (about 5\%), which are produced to prevent attack from predators [5]. However, processing methods such as drying, grating, fermenting and boiling can remove most of the cyanide [6]. And fermentation is considered the most effective method though its effectiveness varies with the period of fermentation $[7,8]$.

The existence of the cyanogenic toxins in cassava poses a health risk, especially when post-harvest processing of cassava fails to eliminate sufficient amounts of the residual cyanide in cassava products. Consumption of such cassava products may present large amounts of toxins which can lead to cyanide poisoning. For instance, it has been reported that 
cyanide ingestion from cassava exacerbates goiter and cretinism in iodine deficient areas and is almost undoubtedly the cause of Konzo in eastern, central and southern Africa $[9,10]$. It is also associated with Tropical ataxic neuropathy (TAN), a long-lasting condition of gradual onset that occurs in older people and causes loss of vision, ataxia of gait, deafness and weakness [11-13]. Other signs and symptoms of cyanide poisoning include vomiting, stomach pains, nausea, diarrhea, dizziness, weakness, headache and even death [14].

There are more than 5000 recognized phenotypically distinctive cassava cultivars [15]. All of them contain varying concentrations of the cyanogenic glycosides, linamarin and lotaustralin, which may range from about $10 \mathrm{mg} / \mathrm{kg}$ to more than $500 \mathrm{mg} / \mathrm{kg}$ fresh weight basis [16]. The content of cyanogenic glycosides in cassava roots is dependent on the cultivar and the growth conditions [17].

Therefore, it is necessary to know the cyanogenic profile of cassava cultivars in a given area so as to optimize the postharvest processing of cassava and regulate the ingestion of cyanogenic toxins.

\section{Materials and Methods}

\subsection{Materials}

The apparatus used during this research included polythene bags, a kitchen knife, refrigerator, containers (basins), distillation flask, reciprocating shaker, $125 \mathrm{~mL}$ Erlenmeyer flasks, filter funnels, filter paper, micro-burette and distillation apparatus. The main reagents that were used during laboratory analysis were sodium hydroxide, 5\% potassium iodide solution, $0.02 \mathrm{~N}$ silver nitrate, and distilled water.

\subsection{Cultivation of Cassava}

A plot of land $(20 \mathrm{~m} \mathrm{x} 7 \mathrm{~m})$ was prepared and 12 ridges were made with $0.5 \mathrm{~m}$ spacing between the ridges. Stem cuttings of six improved cultivars of cassava (NASE 3, NASE 9, NASE 14, NASE 19, TME 14 and TME 204) were obtained from National Agricultural Research Organization (NARO) at Abii Farm in Arua district, Uganda. The stem cuttings of six local cassava cultivars (Nyar-anderiano, Nyapapoga, Nyar-udota, Nya-pamitu, Bisimwenge, and Nyamatia) were collected from local peasant farmers in Zombo district, Uganda. All the above cassava varieties considered are used for human consumption. Each cultivar was planted in a ridge following the order of their names as listed above.

The cuttings from each cultivar, measuring $27 \mathrm{~cm}$ in length, were planted at about $45^{\circ}$ on the crest of the ridges [18]. Care was taken to ensure that the buds were not inverted during planting in order to prevent delayed sprouting [18]. The distance of planting was $0.5 \mathrm{~m} \mathrm{x} 0.5 \mathrm{~m}$ and weeding was done after every four (4) weeks after planting, since the crop was planted as a sole crop [19].

\subsection{Harvesting and Preparation of Cassava Samples}

Since roots of the investigated cassava cultivars are considered to be mature from the age of about twelve months [20-23], samples of the fresh cassava root tubers grown for thirteen months were harvested from each cultivar in the garden using a hoe. After removing the soil, they were transported immediately in polythene bags to the Government Analytical Laboratory (GE058/07) at Wandegeya in Kampala, Uganda. Each of the peeled and washed fresh sample (40.0 g) was weighed and mashed using a wooden pestle and mortar. The samples were then stored at a temperature of $-4^{\circ} \mathrm{C}$ awaiting analysis within 24 hours.

\subsection{Determination of Level of Cyanides in Cassava}

The cassava samples were analyzed by the standard method of FAO [24]. In brief, the sample (10 g to $20 \mathrm{~g}$ ) was put in a $500 \mathrm{ml}$ distillation flask; distilled water (about 200 $\mathrm{ml}$ ) was added and allowed to stand for three hours, in order to set free all the bound hydrocyanic acid. The mixture was distilled with steam and $200 \mathrm{ml}$ of distillate was collected in a solution of $0.625 \mathrm{M}$ sodium hydroxide in water $(20 \mathrm{ml})$. The distillate was then diluted with distilled water to a volume of $250 \mathrm{ml}$.

To the distillate $(100 \mathrm{ml})$ was added potassium iodide solution $(5 \%, 8 \mathrm{ml})$ and titrated with $0.02 \mathrm{~N}$ silver nitrate (1 $\mathrm{ml}$ of $0.02 \mathrm{~N}$ silver nitrate corresponds to $1.08 \mathrm{mg}$ of hydrocyanic acid) using a micro-burette. The end point was indicated by a faint but permanent turbidity, which was recognized easily, especially against a black background.

\subsection{Data Analysis}

A bar graph was generated to show the trend of $\mathrm{HCN}$ levels in the improved and local cassava cultivars. Descriptive statistics for the overall $\mathrm{HCN}$ levels in each of the two cassava varieties (improved and local) were obtained and tabulated with significant variations ascertained using student's t test at 5\% level of significance. Analyses were done with the aid of computer packages; SPSS 17.0 and Microsoft Excel 2007.

\section{Results and Discussion}

\subsection{Levels of Hydrogen Cyanide in the Improved Cassava Varieties at Thirteen Months}

The level of hydrogen cyanide in the improved cassava varieties at 13 months (Figure 1) was highest for NASE 14 $(116.51 \mathrm{mg} / \mathrm{kg})$ and lowest for NASE $19(101.84 \mathrm{mg} / \mathrm{kg})$. The overall mean value was $108.75 \mathrm{mg} / \mathrm{kg}$ (Table 1). Additionally, the variation in cyanide levels in the improved varieties as reflected by the standard deviation was 5.31 (Table 1).

\subsection{Levels of Hydrogen Cyanide in the Local Cassava Varieties at Thirteen Months}

Among the local cassava varieties investigated, Nyarudota $(88.5 \mathrm{mg} / \mathrm{kg})$ and Nyar-anderiano $(90.0 \mathrm{mg} / \mathrm{kg}) \mathrm{had}$ the lowest levels of cyanide, even much lower than for the 
improved varieties. This was consistent with the findings of Emmanuel et al [25] who reported generally low HCN in traditional varieties than improved varieties. The other four local cassava varieties had higher cyanide levels than the improved varieties (Figure 1) contrary to the findings of Emmanuel et al [25]. Overall, the local cultivars had a mean HCN value of $201.65 \mathrm{mg} / \mathrm{kg}$ which was significantly higher than mean value $(108.75 \mathrm{mg} / \mathrm{kg})$ of improved varieties $(\mathrm{t}=$ $2.331, \mathrm{p}=0.042)$.

There was also much variation in the levels of $\mathrm{HCN}$ among the local varieties as evidenced by the relatively higher standard deviation (89.00) as compared to that for improved cassava varieties (Table 1). This appears to be a discovery of new knowledge since a thorough search using a number of search engines did not reveal any information reported about this fact. Therefore, more work could be done to confirm this finding.

The general trend $(\mathrm{mg} / \mathrm{kg})$ in all the twelve varieties considered in this study was: Nyar-udota $(88.50)<$ Nyaranderiano $(90.00)<$ NASE 19 (101.84) < TME 14 (105.60) $<$ NASE $9(107.33)<$ TME $204(107.97)<$ NASE 3 (113.25)
< NASE $14(116.51)<$ Bisimwenge $(181.48)<$ Nya-matia (257.28) < Nya-pamitu (275.97) < Nya-papoga (316.69).

Generally, the improved cassava varieties had lower HCN levels than local cassava varieties, which could be attributed partly to the higher transcriptional activity of the linamarase gene (responsible for the breakdown of the cyanogenic glycosides) in the improved cassava cultivars than the local cassava cultivars [26]. There is also a possibility of more inhibition of the expression of the cytochrome genes that catalyze the first step in linamarin synthesis in the improved varieties than the local varieties. According to Siritunga and Sayre [27], the linamarin content of cassava roots reduced by $99 \%$ in transgenic plants in which the expression of the cytochrome P450 genes (CYP79D1 and CYP79D2) that catalyze the first step in linamarin synthesis, was inhibited.

All the studied cassava varieties had higher cyanide levels than the value of $<10 \mathrm{mg}$ cyanide equivalents/kg dry weight, recommended by $\mathrm{FAO} / \mathrm{WHO}$ [28] to prevent acute toxicity in humans. However, all the values lie within the range of $\mathrm{HCN}$ within cassava root parenchyma of 10-500 mg cyanide equivalents/kg dry weight [27, 29, 30].

Table 1. Descriptive statistics for HCN levels ( $\mathrm{mg} / \mathrm{kg}$ ) in improved and local cassava varieties at thirteen months.

\begin{tabular}{llllll}
\hline Cassava Variety & Mean & SD & SV & Min & Max \\
\hline Improved $(\mathrm{n}=6)$ & 108.75 & 5.31 & 28.15 & 101.84 & 116.51 \\
Local $(\mathrm{n}=6)$ & 201.65 & 89.00 & 7921.31 & 88.50 & 316.69 \\
\hline
\end{tabular}

SD - Standard Deviation, SV - Sample Variation, Min - Minimum, Max - Maximum.

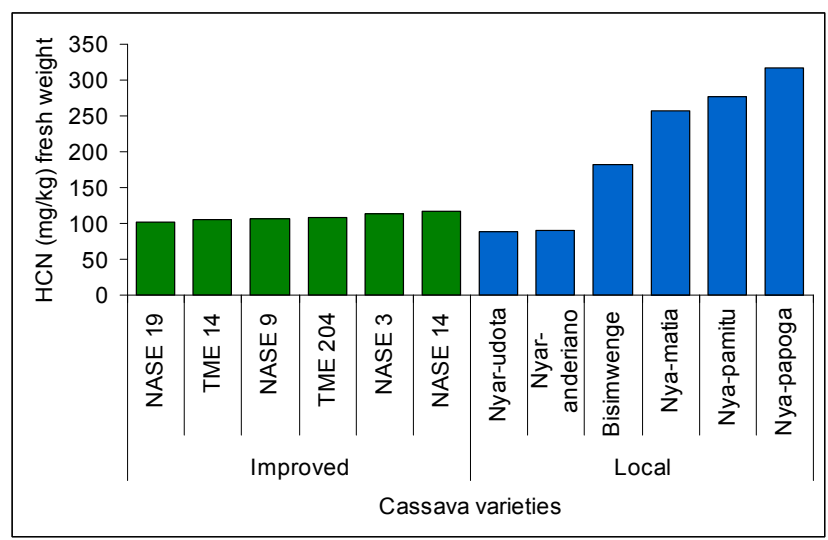

Figure 1. Levels of hydrogen cyanide $(\mathrm{mg} / \mathrm{kg})$ in both improved and local cassava varieties at 13 months.

Cassava can be classified into three groups basing on total cyanide contents, as follows: sweet varieties $(<50 \mathrm{mg} / \mathrm{kg})$, intermediate varieties $(50-100 \mathrm{mg} / \mathrm{kg})$ and bitter varieties $(>$ $100 \mathrm{mg} / \mathrm{kg}$ ) [31-34]. Thus, the studied cassava varieties fall under the intermediate varieties (Nyar-udota, Nyaranderiano) and bitter varieties (NASE 19, TME 14, NASE 9, TME 204, NASE 3, NASE 14, Bisimwenge, Nya-matia, Nyapamitu, Nya-papoga) according to the above classification. But this classification may not be conclusive since cyanogenic content of cassava can also be affected by soil type and nutrient supply $[35,36]$.

\section{Conclusions}

With the exception of Nyar-udota and Nyar-anderiano, the local varieties posted highly fluctuating concentrations of $\mathrm{HCN}$ than the improved cassava varieties which have lower and relatively uniform concentrations of HCN. However, all the improved and local cassava varieties studied had high cyanide levels, above the FAO/WHO recommendations $(<10$ $\mathrm{mg}$ cyanide equivalents/kg dry weight) and thus can cause acute toxicity to humans on consumption without adequate detoxification.

\section{Acknowledgements}

Glory to the almighty God and special recognition to the following: Prof. Christine Dranzoa, Assoc. Prof. Simon K. Anguma, Rev. Fr. Dr. Epiphany Picho Odubuker, and all members of Muni University community, for their support; Mr. Dan Lema, for laboratory analysis of samples; Mr. Alex Abacha, for providing the improved cassava varieties; $\mathrm{Mr}$. Geoffrey Cwothembu, for planting the cassava varieties; $\mathrm{Mr}$. Dominic Macakadhu for identifying and collecting the local cassava varieties. In addition, regards to Mr. Christopher Watumbe, Mr. Charles Onyutha, Rev. Allan Tuape, Mr. Jonathan Brady Wagen-Yesu, Rev. Phinehas Onwang, and Mr. Nzima James Alimudua for their encouragement. Posthumous recognition to Mrs Zila Adubango (RIP), the 
mother and Mr. Ezra Okecha (RIP), the father of the corresponding author.

This paper is dedicated gladly to the DAAD, for their financial support to the corresponding author (Code no.: A/12/94630), through the DAAD In-country Scholarship Uganda, towards his Master's degree programme, which this piece of work was part of.

\section{References}

[1] FAO (Food and Agriculture Organization). FAO, "Food balance sheet," FAO, Rome, 2009a. Accessed at://faostat.fao.org/site/368/default.aspx\#.

[2] Zombo District Socio-Economic Report, Volume II. Subcounty Development Programme: Implementation of The Community Information System (CIS), Uganda Bureau of Statistics, P. O Box 7186 Kampala Website: www.ubos.org, October 2012.

[3] G. W. Otim-Nape, A. Bua, J. M. Thresh, Y. Baguma, S. Ogwal, G. Ssemakula, G. Acola, B. Byabakama, J. Colvin, R. J. Cooter, and A. Martin. 2000. The Current Pandemic of Cassava Mosaic Virus Disease in East Africa and its Control. Natural Resources Institute, Chatham, UK.

[4] A. P. Cardoso, E. Mirione, M. Ernesto, F. Massaza, J. Cliff, M. R. Haque, and J. H Bradbury, "Processing of cassava roots to remove cyanogens," Journal of Food Composition and Analysis, 18, 451-460, 2005.

[5] J. H. Bradbury, and W. D. Holloway, "Chemistry of Tropical Root Crops: Significance for Nutrition and Agriculture in the Pacific," Australian Centre for International Agricultural Research, Monograph No. 6, Canberra, Australia, 1988.

[6] G. Padmaja, "Cyanide detoxification in cassava for food and feed uses," Critical Reviews Food Science Nutrition, 35:299 339, 1995.

[7] M. Andama, and J. B. Lejju, "Potential of Fermentation in Detoxifying Toxic Cassava Root Tubers," Journal of Agricultural Science and Technology, A 2, 1182-1188, 2012.

[8] B. Oloya, C. Adaku, E. Ntambi, and M. Andama, "Detoxification of Nyar-Udota Cassava Variety in Zombo District by Fermentation," International Journal of Nutrition and Food Sciences. Vol. 6, No. 3, 2017, pp. 118-121. doi: 10.11648/j.ijnfs.20170603.11.

[9] F. Delange, L. O. Ekpechi, and H. Rosling, "Cassava cyanogenesis and iodine deficiency disorders," Acta Horticulture, 375, 289-293, 1994.

[10] M. Ernesto, A. P. Cardoso, D. Nicala, E. Mirione, F. Massaza, J. Cliff, M. R. Haque and J. Bradbury, "Persistent konzo and cyanide toxicity from cassava in Northern Mozambique," Acta Tropica, 82:357-362, 2002.

[11] B. O. Osuntokun, "Chronic cyanide intoxication of dietary origin and a degenerative neuropathy in Nigerians," Acta Horticulturae, 375, 311-321, 1994.

[12] W. P. Howlett, "Konzo; a new human disease entity," Acta Horticulturae, 375, 323-329, 1994.

[13] A. O. Onabolu, O. S. A. Oluwole, M. Bokanga, and H. Rosling, "Ecological variation of intake of cassava food and dietary cyanide load in Nigerian communities," Public Health Nutrition, 4, 871-876, 2001.

[14] A. Akintonwa, O. Tunwashe, and A. Onifade, "Fatal and nonfatal acute poisoning attributed to cassava-based meal," Acta Horticulturae, 375, 285-288, 1994.

[15] R. Best, and T. R. Hargrove, "Cassava: The latest facts about an ancient crop," International Centre for Tropical Agriculture, Cali, Colombia. 1993.

[16] G. M. O'Brien, C. C. Wheatley, C. Iglesias, and N. H. Poulter, "Evaluation, modification, and comparison of two rapid assays for cyanogens in cassava," Journal of the Science of Food and Agriculture, 65, 391-399, 1994.

[17] M. R. Grace, "Elaboration of cassava. FAO Collection: Plant Protection and Protection," Food and Agriculture Organization of the United Nations, Rome, Italy, pp 1-162, 1977.

[18] N. B. Okigbo, "Nutritional implications of projects giving high priority to the production of staples of low nutritive quality. The case of cassava in the humid tropics of West Africa," Food and Nutrition Bulletin, 2(4). United Nations University, Tokyo, 1980.

[19] A. Melinfonwu, B. James, K. Achou, S. Weise, E. Awah, and B. Gbaguidi, "Weed Control in Cassava Farms," IPM Field Guide for Extension Agent, 2002.

[20] O. S. A. Oluwole, A. O. Onabolu, K. Mtunda, and N. Mlingi, "ARTICLE IN PRESS Characterization of cassava (Manihot esculenta Crantz) varieties in Nigeria and Tanzania, and farmers' perception of toxicity of cassava," vol. 20, pp. 559567, 2007.

[21] Sriroth, K, Santisopasri, V., Petchalanuwat, C., Piyachomkwan, K., Kurotjanawon, K., \& Oates, C. (1999), "Cassava Starch Granule Structure- Functional Properties: Influence of Time and Condition at Harvest on Four Varieties of Cassava Starch", Carbohydrate Polymers, 38 (2), 161 170.

[22] M. Ngendahayo, and A. G. O. Dixon, "Effect of varying stages of harvest on tuber yield, dry matter, starch and harvest index of cassava in two ecological zones in Nigeria," In: root crops in 21st century. Proceedings of the 7th Triennial Symposium of the ISTRC-AB (M. O. Akoroda and J. M. Ngeve Eds). Cotonou, Benin, pp 661-667, 1998.

[23] E. U. Odigboh, "'A Cassava Peeling Machine: Development, Design and Construction", Journal of Agricultural Engineering Research, 21, 361-369, 1976.

[24] FAO, "Processing and utilization of Root and Tuber Crops," FIAT PANIS; Rome, 2000.

[25] O. A. Emmanuel, A. Clement, S. B. Agnes, L. Chiwona Karltun, and B. N. Drinah, "Chemical composition and cyanogenic potential of traditional and high yielding CMD resistant cassava (Manihot esculenta Crantz) varieties" International Food Research Journal 19(1): 175-181, 2012.

[26] M. A. Santana, V. Vásquez, J. Matehus, and R. R. Aldao. "Linamarase Expression in Cassava Cultivars with Roots of Low- and High-Cyanide Content." Plant Physiology 129, no. 4 (2002): 1686-694.

[27] D. Siritunga, and R. T Sayre, "Generation of cyanogens free transgenic cassava," Planta 217: 367-73, 2003. 
[28] FAO/WHO. 1991. Joint FAO/WHO food standards programme. In: Codex Alimentarius Commission XII (suppl. 4). Rome, Italy: FAO.

[29] P. Arguedas and R. D. Cooke, "Residual Cyanide Concentration During the Extraction of Cassava Starch," Food Technol., vol. 17, pp. 251-261, 1982.

[30] D. L. Dufour, "Cyanide Contents of Cassava (Manihot esculenta, Euphorbiaceae) Cultivars Used by Tukanoan Indians in North-west Amazonia," Economic Botany, 42 (2): 255-266, 1988 .

[31] G. G. Bolhuis, "The toxicity of cassava roots". Journal of Agriculture and Science, 2:176-185, 1954.

[32] H. Rosling, "Cassava toxicity and food security". Uppsala, Sweden, Tryclc Kontakt, 40 p. 1987.
[33] R. Rukiya, "Détermination quantitative du cyanure dans le manioc (variétés F100, 02864, 30085/28, 30344/6 Mpelolongi)". Inédit. Mémoire. Faculté des sciences, Université de Kinshasa. 1988.

[34] B. Nambisan, "Strategies for elimination of cyanogens from cassava for reducing toxicity and improving food safety", Food and Chemical Toxicology, 49: 690-693, 2011.

[35] G. H. de Bruijn, "The cyanogenic character of cassava (Manihot esculenta)". In B Nestel, R MacIntyre, eds, Chronic Cassava Toxicity: Proceedings of an Interdisciplinary Workshop, January 29-30, 1973, London. International Development Research Centre, Ottawa, pp 43-48, 1973.

[36] M. Bokanga, I. J. Ekanayake, A. G. O. Dixon, M. C. M. Porto, "Genotype-environment interactions for cyanogenic potential in cassava”. Acta Horticulture 375: 131-139, 1994. 